ONLINE MUTATION REPORT

\title{
Clinical features of type 2 Stickler syndrome
}

\author{
A V Poulson, J M M Hooymans, A J Richards, P Bearcroft, R Murthy, D M Baguley, J D Scott, \\ M P Snead
}

J Med Genet 2004;41:e107 (http://www.jmedgenet.com/cgi/content/full/41/8/e107). doi: 10.1136/jmg.2004.018382

$\mathrm{T}$ he Stickler syndromes ${ }^{1-8}$ (hereditary arthro-ophthalmopathy; McKusick nos. 108300 and 604841) are one of the more frequently occurring groups of chondrodysplasias and are the commonest inherited cause of rhegmatogenous retinal detachment. ${ }^{9}$ The majority of patients and pedigrees exhibit the type 1 or "membranous" vitreous phenotype ${ }^{10} 11$ and harbour mutations in the gene for type II collagen $(C O L 2 A I){ }^{12-21}$ While not all mutations in type II collagen result in the membranous vitreous anomaly, ${ }^{22}{ }^{23}$ when it is exhibited it appears to be congenital and provides a useful basis for mutant locus assignment. This is particularly helpful for sporadic cases where linkage is impossible, and especially in those individuals with mild or minimal systemic involvement where the diagnosis might otherwise be overlooked. ${ }^{19}{ }^{24-26}$ Other pedigrees exhibit a different "beaded" vitreous phenotype and are linked to a different locus. ${ }^{1127} \mathrm{We}$ reported the first mutation in the gene encoding the $\alpha$ l chain of type XI collagen (COL1IAI) in one of these pedigrees ${ }^{28}$ and this locus was confirmed in other pedigrees, ${ }^{29} 30$ and is now known as type 2 Stickler syndrome (McKusick no. 604841). The intimate post-translational molecular associations between types II and XI collagen form the foundation of the close clinical overlap between these two sub-groups of Stickler syndrome, but the extent of this clinical overlap and variation remains to be defined. Whilst type l Stickler syndrome pedigrees have a particularly high risk of blindness through giant retinal tear and retinal detachment, Annunen et al suggest that patients with COL11Al mutations are at a low risk of retinal detachment and have a higher incidence of midfacial hypoplasia. ${ }^{29}$ This would be an important prognostic difference if confirmed. Here we wish to report the first description of the ophthalmic, oro-facial, audiologial, skeletal, and echocardiographic features of a large cohort of patients with type 2 Stickler syndrome in which molecular genetic analysis has confirmed mutations in COL11A1.

\section{METHODS}

Five pedigrees with Stickler syndrome, all exhibiting the beaded or type 2 vitreous phenotype, were identified from the Vitreous Research Clinic at Addenbrooke's Hospital, Cambridge, UK. Ethical approval was granted (LRC92/019) and informed written consent was received in all cases. A sixth pedigree was identified via our collaboration with the University Hospital of Groningen, Netherlands.

The diagnostic criteria used to identify the index cases were modified from those previously published for type I Stickler syndrome ${ }^{11}$ and are as follows: a "major" criterion: "beaded" vitreous anomaly and, in addition, any three of the following "minor" criteria:

1. Myopia with onset before 6 years of age.

2. Rhegmatogenous retinal detachment or paravascular pigmented lattice retinopathy.

3. Joint hypermobility with abnormal Beighton score, with or without radiological evidence of joint degeneration.

\section{Key points}

- The clinical features of patients with type 2 Stickler syndrome with confirmed mutations in the gene encoding the $\alpha 1$ chain of type XI collagen (COL1 1A1) are described.

- Six pedigrees, all exhibiting the beaded or type 2 vitreous phenotype, were identified. Ophthalmic, orofacial, skeletal, and audiological features were assessed in addition to echocardiography. Linkage analysis was carried out with markers for the candidate genes COL2A1, COL11A1, and COL11A2. Amplification and sequencing of COL11A1 CDNA was achieved using RNA from cultured dermal fibroblasts.

- Thirty one affected members from the six pedigrees were identified. Of these $87 \%$ were myopic and $38 \%$ had paravascular lattice retinopathy, $64 \%$ had a cataract and five exhibited the wedge-shaped cortical opacities typical of Stickler syndrome. Forty two per cent had suffered retinal detachment, 19\% bilaterally. The average age at which retinal detachment occurred was 34 years (range 9-55). Thirty seven per cent showed evidence of midline clefting and $80 \%$ were found to have mild (asymptomatic) or moderate high tone sensorineural hearing loss. No patient had evidence of mitral valve prolapse.

- Type 2 Stickler pedigrees with confirmed mutations in COL1 1A1 have a high risk of retinal detachment. The facial phenotype is highly variable. The diagnosis, which can be determined by observation of the vitreous phenotype, can be helped by audiological evidence of sensorineural deafness.

4. Audiometric confirmation of sensorineural hearing defect.

5. Midline clefting (bifid uvula, submucous cleft, high arch palate, cleft repair, Pierre Robin sequence).

Ophthalmic, oro-facial, skeletal, and audiologial features were assessed using the methods reported previously ${ }^{19}$ in addition to echocardiography. A general ophthalmic history was recorded with particular attention to the age of onset, degree and progression of myopia, cataract, and vitreoretinal disease. A full ophthalmic examination was carried out. In some of the younger patients applanation tonometry and gonioscopy were not possible. Anterior and posterior segment photographs were taken where appropriate.

Orofacial features were assessed according to standard protocols. ${ }^{31}$ Antero-posterior and lateral facial photographs at a standardised scale of 1:8 using a Nikon FM2 camera with Micro Nikon 105 mm medical lens and Kodachrome 64 film 
at F16. A $1 \mathrm{~cm}$ grid was printed and then photographed at a scale of 1:8 to match and clinical measurements of outer canthal distance, inner canthal distance, philtrum length, and middle finger length were also recorded. These measurements were used as controls for the photographic calibration. Control measurements of inner and outer canthal distance, interpupillary distance, and philtrum length from 20 unaffected siblings and 60 age matched controls (recruited from the general ophthalmic clinic) were also recorded.

Joint hypermobility was assessed objectively using the Beighton scoring system. ${ }^{32}$ A score of 1 or 0 is given for a series of joint manoeuvres and the total sum allocated up to a possible maximum score of $9 / 9$.

An enquiry was made regarding the date and progression of any subjective hearing loss and, in particular, whether this had been a congenital, sudden, or progressive deterioration. A record of the type and duration of noise exposure was made together with any factors likely to contribute a conductive element to any hearing loss. All affected patients underwent bilateral otoscopy and audiometry involving air and bone conduction testing according to standardised procedures. ${ }^{33}$

Patients were questioned about their cardiovascular history and underwent a full cardiological examination including auscultation and 2-D echocardiography. Echocardiographic studies were carried out using a Hewlett-Packard Sonos 1000 with $3.5-2.5 \mathrm{MHz}$ phased array transducers. Echocardiographic views consisted of long and short axes, apical four and apical two chambers, incorporating conventional pulsed and colour flow Doppler.

For the large families MS1, MS40, MS42, and JH1, linkage analysis was carried out with flanking and/or intragenic markers for the candidate genes COL2A1, COL11A1, and COL11A2 as previously described. ${ }^{30}$ For MS67 and MS71, analysis of COL11A1 was performed on the basis of vitreous phenotype. Amplification and sequencing of COLllAl cDNA was achieved using RNA from cultured dermal fibroblasts. ${ }^{28} 30$

\section{RESULTS}

A total of 31 affected members from six pedigrees were identified. The pedigrees are shown in fig 1.

All patients exhibited the "beaded" vitreous phenotype (fig 2) and had confirmed mutations in the $\alpha$ l chain of type XI collagen (COL1IAI) shown in table 1. The Dutch family $\mathrm{JHl}$ was found to have the same mutation as the British family MS42.

\section{Clinical features}

Twenty patients (65\%) were female and 11 (35\%) male. The ages ranged from 10 to 84 years with an average age of 38 . The clinical features are summarised in table 2 .

\section{Ophthalmic}

A total of $87 \%$ of patients were short sighted (myopic) and 14 $(52 \%)$ of the patients reported their myopia to be stable. Some unaffected individuals exhibiting a normal vitreous phenotype were also myopic, including one of non-identical twins, MS40 IV:5, emphasising the importance of vitreous phenotype as a marker for the disorder.

Some $64 \%$ of patients either had cataract or were aphakic or pseudophakic. Of the phakic patients with cataract, 33\% (5/15) exhibited the wedge-shaped lens opacity peculiar to Stickler syndrome ${ }^{34} 35$ and some sporadic cases of rhegmatogenous retinal detachment (fig 3).

A total of $38 \%$ had pigmented paravascular lattice. Thirteen patients $(42 \%)$ suffered retinal detachment. Six had bilateral retinal detachment, one with bilateral giant retinal tears. The average age at which retinal detachment had occurred was
34 years with a range of 9-55 years. Two patients had retinal detachment under the age of 16.

\section{Orofacial}

One third of patients were found to have variable manifestations of mid-line clefting including bifid uvula, high arched palate, and cleft palate. Facial features were in general more subtle than those seen in type 1 Stickler syndrome with mild mid-facial and nasal hypoplasia. In some affected individuals the facial phenotype did not vary significantly from age/sex matched controls ${ }^{31}$ (fig 4).

Seven patients had lateral skull $x$ rays. Four were normal (normal calvaria and frontal sinuses). Of the three abnormal cases, in one the frontal sinus was absent; in another it was small and, in contrast, large in the third.

No patient had any abnormalities of skin, hair, or sweating as reported in Marshall syndrome. ${ }^{36}$

\section{Skeletal}

One third of patients exhibited or reported previous joint laxity (fig 5) with almost half experiencing symptoms of arthritis (most frequently knees, ankles, back, and wrists).

\section{Audiological}

A total of $45 \%$ of patients reported symptomatic hearing loss but, of those tested, 20/25 (80\%) had some degree of high frequency sensorineural hearing loss ranging from mild $(30 \mathrm{~dB})$ to moderate $(30-60 \mathrm{~dB})$ loss. No patient reported profound deafness in either ear. Three patients had mild or moderate conductive hearing loss in addition to sensorineural loss

\section{Mitral valve prolapse}

None of the 12 patients who underwent echocardiography had mitral valve prolapse.

\section{DISCUSSION}

This is the first report describing the clinical features of type 2 Stickler syndrome. All patients have a proven mutation in COL1IAl and exhibited the "beaded" type 2 vitreous phenotype.

The range of clinical features is similar to those in type 1 Stickler syndrome, with variability between and within families, but with a particularly high prevalence of sensorineural hearing loss which is often mild enough to go unnoticed by the patient. In contrast to the study by Annunen et al, this study confirms that individuals are indeed at high risk of retinal detachment, $42 \%$ of this group having suffered a retinal detachment in at least one eye at the time of study.

There has been some confusion in the literature regarding the vitreous phenotypes of type 1 and type 2 Stickler syndrome. It is important to recognise that the type 1 anomaly is a congenital and not a degenerative manifestation. Following a case report by Parentin et al, ${ }^{37}{ }^{38}$ McLeod et $a l^{39}$ have suggested that observation of the vitreous phenotype is not reliable in distinguishing between type 1 and type 2 Stickler syndromes. The pedigree reported by Parentin et $a l^{37}{ }^{38}$ was classified as type l Stickler syndrome but linkage analysis was thought to favour COL11Al rather than COL2A1, although no mutation analysis was performed. The description in the manuscript of the vitreous phenotype suggested type l Stickler syndrome, but the photographs included in the paper did not demonstrate the type 1 vitreous anomaly. All three patients, in whom the vitreous had been commented upon, had bilateral retinal detachment. An alternative explanation is that the type 1 vitreous anomaly was confused with the detached posterior hyaloid membrane. In addition, the implication of COLIIAl was only weakly 
$\mathrm{JH} 1$

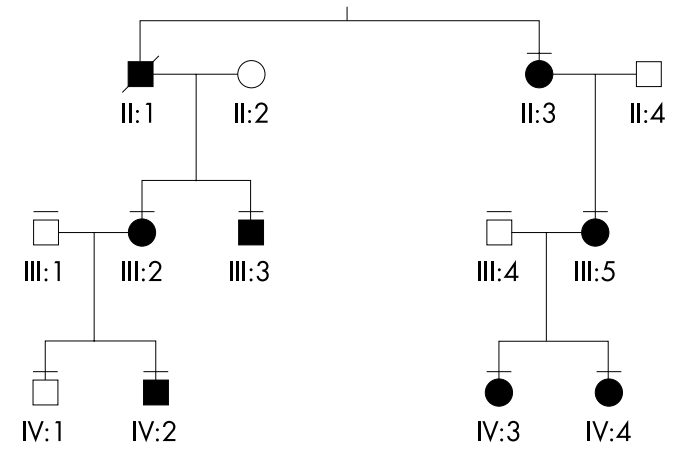

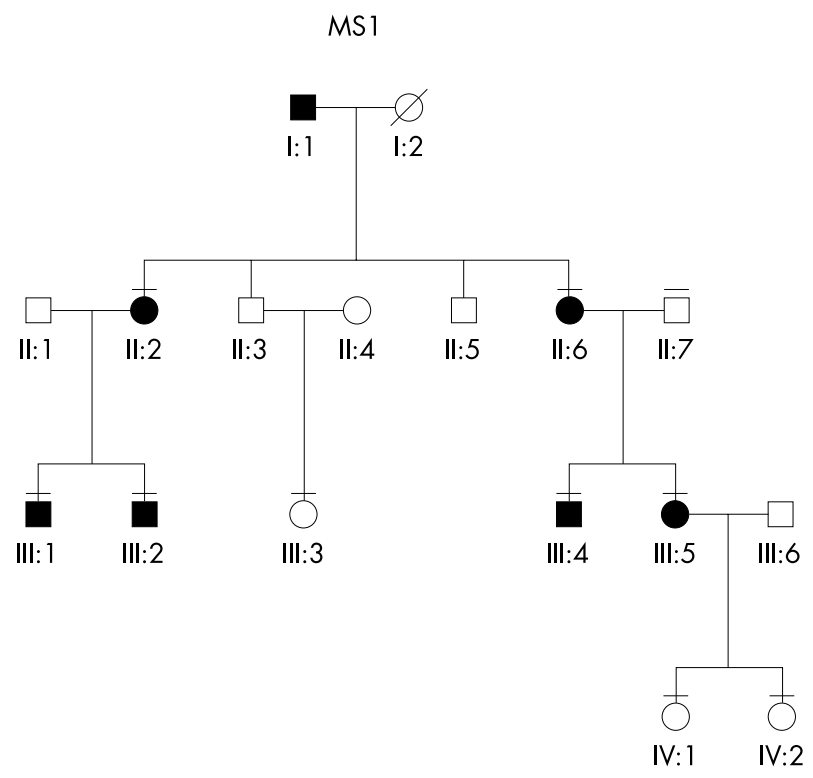
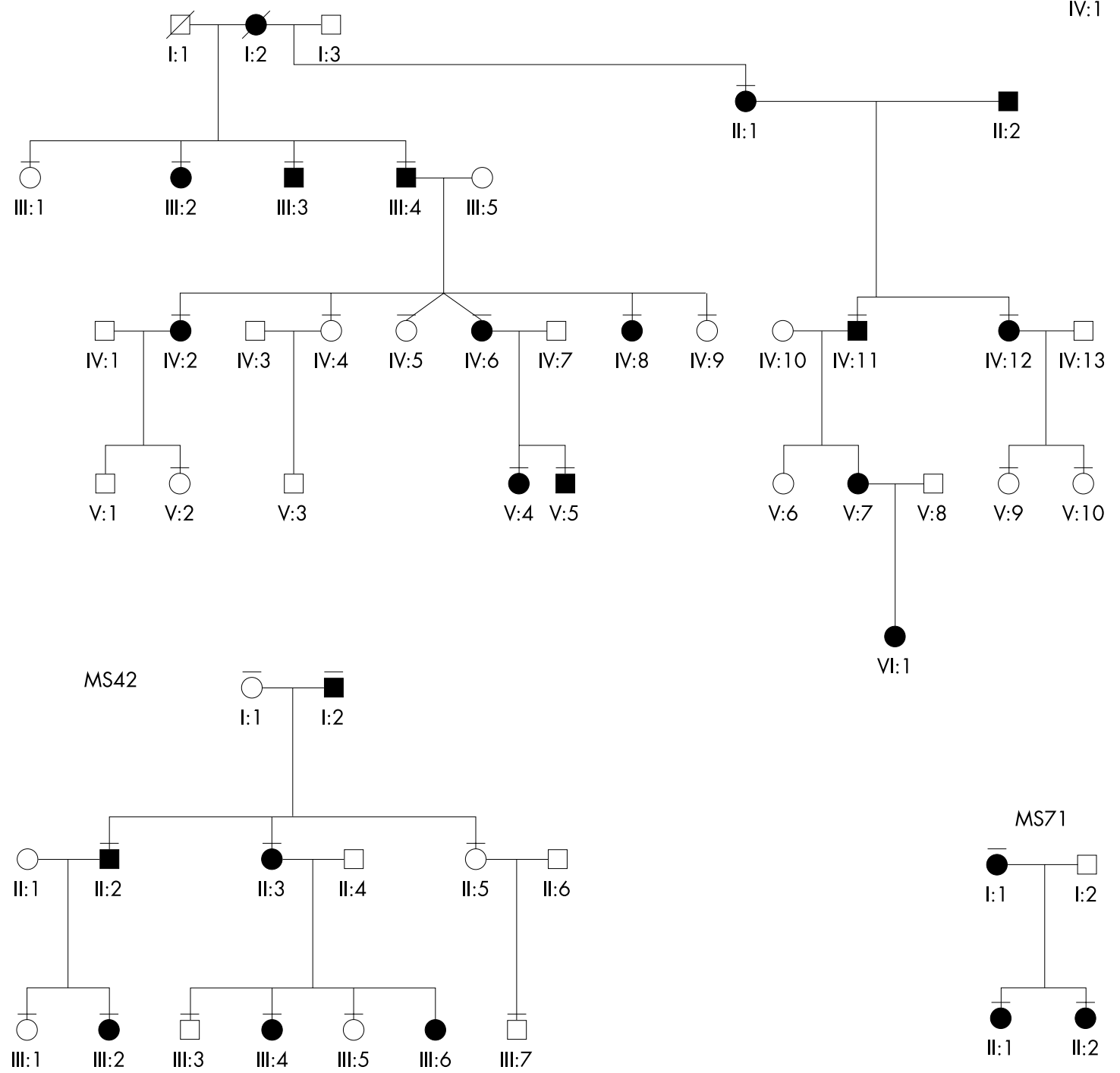

Figure 1 Type 2 Stickler syndrome pedigrees. The sixth pedigree consists of one member MS67 I:1. 

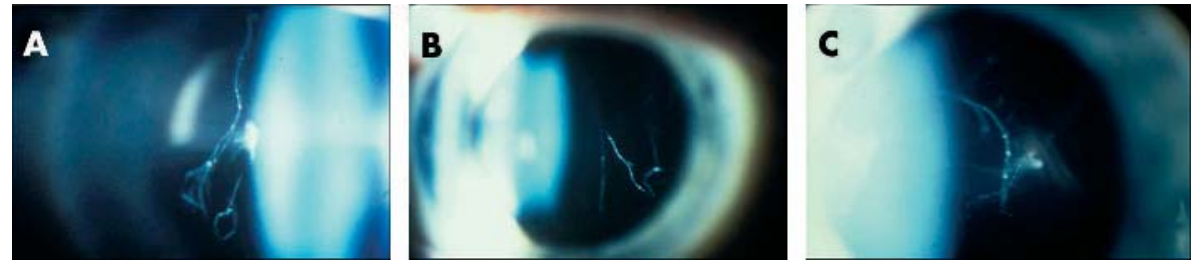

Figure 2 "Beaded" vitreous phenotype: (A, B) MS42 III:2; (C) MS42 II:2.

supported by the linkage analysis, whilst the markers used for the linkage analysis did not adequately exclude a mutation in COL2Al as they did not flank both sides of the gene.

McLeod et al ${ }^{39}$ also describe two affected members of a type 2 Stickler syndrome pedigree (with a COL11A1 mutation confirmed) and report that the vitreous phenotype appeared to change from a type 2 anomaly to a type 1 anomaly with the development of a posterior vitreous detachment. In contrast to the congenital type 1 vitreous anomaly, the posterior hyaloid membrane is visible only after posterior vitreous detachment and is clearly a separate entity. ${ }^{40}$ Both membranes can be demonstrated in the same eye when a patient with type 1 Stickler syndrome develops a posterior vitreous

\begin{tabular}{|llll|}
\hline Table 1 & COL1 1A1 mutations & & \\
\hline ID & cDNA mutation & Genomic DNA mutation & Reference \\
\hline MS1 & G-T G97V & G-T G97V & Richards et al, 1996 \\
MS40 & 774 bp deletion & Exon 31-42 deletion & Martin et al, 1999 \\
MS42 & Exon 15 skip (54 bp) & IVS 14 A-2 del & Martin et al, 1999 \\
MS67 & Exon 52 skip (54 bp) & IVS 52 G+1 - A+1 & This report \\
MS71 & Exon 61 skip (36 bp) & IVS 60 A-2 - G-2 & This report \\
JH1 & Exon 15 skip (54 bp) & IVS 14 A-2 del & This report \\
\hline & & & \\
& & & \\
\hline
\end{tabular}

Table 2 Clinical features of patients with type 2 Stickler syndrome

\begin{tabular}{|c|c|c|c|c|c|c|c|c|c|c|}
\hline \multirow{2}{*}{\multicolumn{2}{|c|}{ Pedigree number }} & \multirow{3}{*}{$\begin{array}{l}\text { Age } \\
21\end{array}$} & \multicolumn{2}{|c|}{ Ocular phenotype } & \multicolumn{2}{|c|}{ Articular phenotype } & \multicolumn{2}{|c|}{ Aural phenotype } & \multicolumn{2}{|c|}{ Oro-facial phenotype } \\
\hline & & & \multirow{2}{*}{$\begin{array}{l}\text { Myopia* } \\
+\end{array}$} & \multirow{2}{*}{$\begin{array}{l}\text { RDt } \\
++\end{array}$} & \multirow{2}{*}{$\begin{array}{l}\begin{array}{l}\text { Joint } \\
\text { hypermobility }\end{array} \\
0\end{array}$} & \multirow{2}{*}{$\begin{array}{l}\text { Radiological } \\
\text { abnormality }\end{array}$} & \multirow[t]{2}{*}{$\begin{array}{l}\text { Conductive } \\
\text { lossł }\end{array}$} & \multirow[t]{2}{*}{$\begin{array}{l}\text { Sensorineural } \\
\text { loss } \ddagger\end{array}$} & \multirow{2}{*}{$\begin{array}{l}\begin{array}{l}\text { Midface } \\
\text { hypoplasia }\end{array} \\
0\end{array}$} & \multirow{2}{*}{$\begin{array}{l}\text { Cleft§ } \\
0\end{array}$} \\
\hline $\mathrm{JHI}$ & IV:3 & & & & & & & & & \\
\hline $\mathrm{JHI}$ & $\mathrm{IV}: 2$ & 10 & + & 0 & 0 & & 0 & 0 & & 0 \\
\hline $\mathrm{JHI}$ & III:5 & 49 & + & + & 0 & & & & 0 & 0 \\
\hline JHI & III:3 & 34 & + & Cryo & 0 & & & & & +++ \\
\hline $\mathrm{JHI}$ & III:2 & 42 & ++ & + & 0 & & & & 0 & +++ \\
\hline $\mathrm{JHI}$ & II:3 & 84 & + & Laser & 0 & & & & 0 & 0 \\
\hline $\mathrm{JHI}$ & IV:4 & 18 & + & + & 0 & & 0 & 0 & + & +++ \\
\hline MS1 & III:4 & 32 & +++ & + & + & & ++ & ++ & & +++ \\
\hline MS1 & III:5 & 34 & +++ & + & 0 & & 0 & + & + & 0 \\
\hline MSI & III:2 & 28 & ++ & Cryo & + & & 0 & + & + & +++ \\
\hline MS1 & III: 1 & 31 & ++ & + & 0 & & 0 & 0 & + & 0 \\
\hline MS1 & II:6 & 59 & ++ & 0 & 0 & & 0 & + & + & + \\
\hline MSI & $\|: 2$ & 55 & + & + & 0 & & 0 & ++ & 0 & 0 \\
\hline MS40 & III:3 & 63 & ++ & 0 & 0 & + & 0 & ++ & 0 & 0 \\
\hline MS40 & III:2 & 68 & +++ & + & ++ & + & 0 & ++ & + & 0 \\
\hline MS40 & IV:12 & 43 & 0 & 0 & 0 & $0 /+$ & 0 & + & + & 0 \\
\hline MS40 & IV:11 & 47 & 0 & 0 & + & & 0 & ++ & + & 0 \\
\hline MS40 & III:4 & 57 & + & + & 0 & + & & & + & ++ \\
\hline MS40 & II: 1 & 65 & + & + & 0 & + & 0 & ++ & 0 & 0 \\
\hline MS40 & $\mathrm{IV}: 2$ & 36 & + & 0 & ++ & 0 & 0 & + & + & 0 \\
\hline MS40 & IV:6 & 34 & 0 & 0 & 0 & 0 & 0 & 0 & + & 0 \\
\hline MS40 & IV:8 & 32 & + & 0 & 0 & + & 0 & + & 0 & 0 \\
\hline MS42 & $\mathrm{I}: 2$ & 73 & + & + & 0 & + & 0 & + & + & 0 \\
\hline MS42 & $\|: 3$ & 41 & + & + & 0 & & 0 & + & ++ & 0 \\
\hline MS42 & III:2 & 14 & + & 0 & 0 & 0 & 0 & 0 & 0 & 0 \\
\hline MS42 & III: 4 & 12 & ++ & 0 & 0 & & 0 & + & + & ++ \\
\hline MS42 & $\|: 2$ & 44 & + & Laser & 0 & + & 0 & + & + & 0 \\
\hline MS67 & I: 1 & 19 & +++ & 0 & + & & + & ++ & + & \\
\hline MS71 & I:1 & 47 & + & 0 & ++ & & 0 & + & + & ++ \\
\hline MS71 & II:1 & 17 & ++ & 0 & ++ & & + & ++ & + & +++ \\
\hline MS71 & $\|: 2$ & 11 & 0 & 0 & ++ & & + & + & + & +++ \\
\hline
\end{tabular}

0 : absent; +: mild; ++: moderate; +++ : severe

*0: not myopic; +: mild $(<-5)$; ++: moderate $(-5$ to -10$)$; +++: high $(>-10)$; †Retinal detachment (RD): 0 : no RD; +: RD in one eye; ++: RD in both eyes; cryo/ laser: prophylactic cryo or laser retinopexy; $¥ 0$ : none; +: mild $30 \mathrm{~dB}$; ++ : moderate $30-60 \mathrm{~dB}$; +++: severe $>60 \mathrm{~dB}$; $\$ 0$ : none; +: bifid uvula; ++: high arched; +++ : cleft palate.

All patients exhibited the "beaded" vitreous phenotype and had confirmed mutations in the $\alpha 1$ chain of type XI collagen (COL1 1Al). 

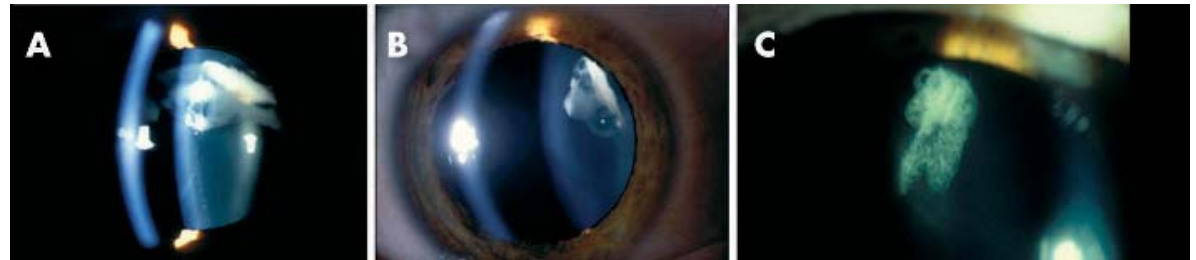

Figure 3 Characteristic cortical cataract: (A) MS40 IV:2; (B) MS1 III:2; (C) MS1 III:5.

detachment. The posterior hyaloid membrane differs in its position, its movement, and the degree of surface crinkling. We believe the suggestion that the type 2 phenotype can convert to the type 1 phenotype is misleading.

The "beaded" type 2 vitreous anomaly is less easy to distinguish but, as our study demonstrates, is sufficiently characteristic to be a useful clinical hallmark differentiating type 2 from type 1 Stickler syndrome.

In contrast to the findings of Liberfarb and Goldblatt ${ }^{41}$ who found that over $45 \%$ of their patients had mitral valve prolapse, Ahmad et al ${ }^{42}$ looked at 78 patients who included both type 1 and the type 2 Stickler syndrome patients included in this study and found that none had mitral valve prolapse.

Other disorders have been reported to share some of the features of Stickler syndrome. Wagner ${ }^{43}$ reported a large Swiss family with an autosomal dominant vitreoretinal disorder resembling Stickler syndrome but without retinal detachment. Analysis of the original Wagner pedigree has shown linkage to $5 \mathrm{ql} 3-\mathrm{ql} 4,{ }^{44}$ confirming that it is genetically distinct from Stickler syndrome. The original WeissenbacherZweymuller syndrome patient ${ }^{45}$ was found to be heterozygous for a mutation in COL11A2. ${ }^{46}$ Although, in cartilage, the $\alpha 2(\mathrm{XI})$ collagen forms heterotrimers with $\alpha \mathrm{l}$ (XI) collagen, it is not expressed in the eye and thus there are no associated eye changes. The term non-ocular Stickler syndrome (McKusick no. 184840) encompassing COL11A2 disorders has been suggested.

There is continuing debate over the clinical overlap and differential diagnosis of Stickler and Marshall syndromes. ${ }^{29}{ }^{47-49}$ Marshall $^{36}$ described seven members in a three generation pedigree who were affected with a hereditary "ectodermal dysplasia" with ocular abnormalities and hearing defect. The pedigree showed autosomal dominant inheritance, normal stature but diminished sweating, and abnormal teeth. Hair and nails were normal. All patients
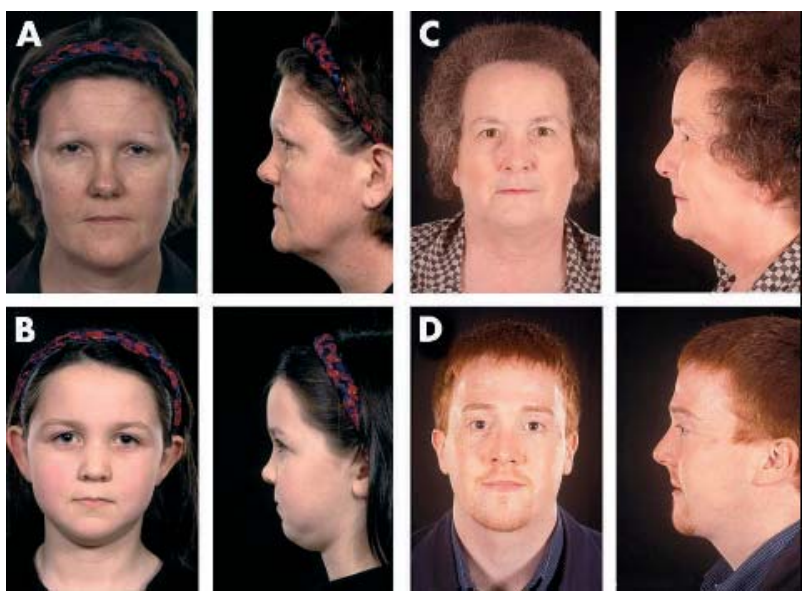

Figure 4 Facial phenotype: (A) MS71 I:1 ; (B) MS71 II:2; (C) MS1 II:6; (D) MS1 III:2. were myopic (moderate to high) with fluid vitreous, although the vitreous phenotype was not described in detail. Several affected individuals had congenital or juvenile cataract which underwent sudden maturation, some with lens subluxation and secondary glaucoma. At the age of 43, one patient suffered a retinal detachment, 9 months following traumatic lens dislocation. Otherwise, there were no localised retinal lesions. In contrast to the series of patients described here, all the patients reported by Marshall had a short, depressed nose and an underdeveloped maxilla. $x$ Rays showed a thickening of the outer table of the skull and absent frontal sinus in two siblings. Midline clefting and arthropathy were not reported although one patient had mild postural scoliosis. Shanske et $a^{50}$ argue that photographs published in Marshall's original paper also show that several of the patients have striking ocular hypertelorism, and confirm that Marshall syndrome is a rare condition, with only eight additional reports since 1958. In two of these reports cited by Shanske et al, the authors did not consider their patients to have Marshall syndrome. $^{5152}$ The distinction between the Stickler and Marshall syndromes is complicated by further reports describing Marshall syndrome but with features that were
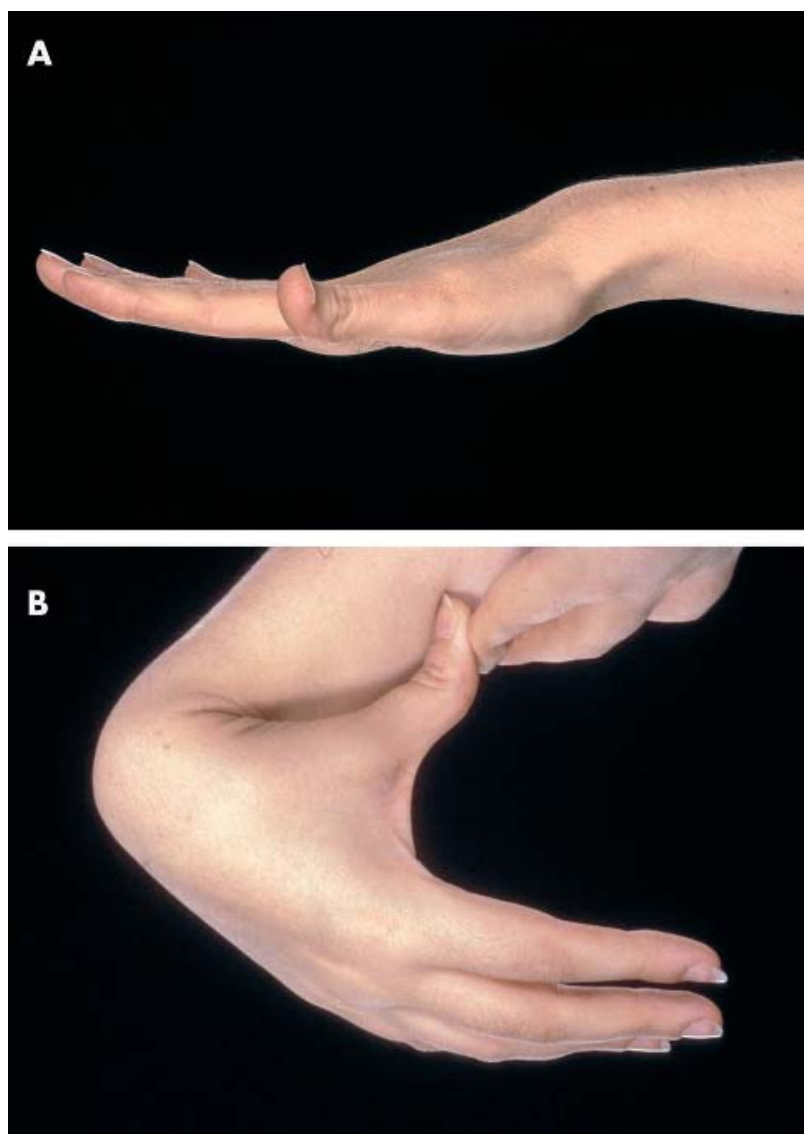

Figure 5 Joint hypermobility: (A) MS71 I:1, (B) MS67 I:1 
not described in the original Marshall kindred, and yet are known features in cases of Stickler syndrome confirmed by molecular genetic analysis. Annunen et $a^{29}$ described a series of patients with mutations in COLIIAI and COL2AI and found similar clinical findings in patients with mutations in either gene. The notable differences were that those with COL1IAl mutations more commonly had severe hearing impairment and seldom had vitreoretinal degeneration or retinal detachment. Those with COL11Al mutations were classified as having Marshall syndrome or an overlapping Marshall-Stickler syndrome, whilst those with COL2Al mutations were considered to have Stickler syndrome. The controversy will continue until the molecular genetic basis of the original Marshall pedigree is resolved.

In the continuing search for a clinical distinction between Stickler syndrome and Marshall syndrome, concentration on subtle facial differences may detract from recognising the serious risk of retinal detachment. This study demonstrates the importance of the vitreous phenotype in the diagnosis of Stickler syndrome, even in those individuals who appear clinically normal in other aspects of the disorder. Recognising the risk to the individual and to members of the family allows appropriate steps to be taken to educate, offer genetic counselling, consider prophylaxis, and offer prompt remedial treatment.

\section{ACKNOWLEDGEMENTS}

The authors gratefully acknowledge the help of the Stickler Syndrome Support Group, Gillian Whitmore and Katherine Haslam.

\section{Authors' affiliations \\ A V Poulson, R Murthy, J D Scott, M P Snead, Vitreoretinal Service, Addenbrooke's NHS Trust, Cambridge, UK \\ J M M Hooymans, Department of Ophthalmology, University Hospital of Groningen, Groningen, Netherlands \\ A J Richards, Department of Pathology, University of Cambridge, Cambridge, UK \\ P Bearcroft, Department of Radiology, Addenbrooke's NHS Trust, Cambridge, UK \\ D M Baguley, Department of Audiology, Addenbrooke's NHS Trust, Cambridge, UK}

This research is funded by grants from The Guide Dogs for the Blind Association, The Isaac Newton Trust, The Stanley Thomas Johnson Foundation, Action Medical Research and The University of Cambridge Retinal Research Fund.

Conflict of interest: none declared.

Correspondence to: M P Snead, Vitreoretinal Service, Box 41, Addenbrooke's NHS Trust, Hills Road, Cambridge, CB2 2QQ, UK; mps34@cam.ac.uk

Revised version received 29 February 2004

Accepted for publication 1 March 2004

\section{REFERENCES}

1 Stickler GB, Belau PG, Farrell FG, Jones J, Pugh DG, Steinberg AG, Ward LE. Hereditary progressive arthro-ophthalmolpathy. Mayo Clin Proc 1965;40:433-55.

2 Stickler GB, Pugh DG. Hereditary progressive arthro-ophthalmology II. Additional observations on vertebral abnormalities, a hearing defect, and a report of a similar case. Mayo Clin Proc 1967;42:495-500.

3 Hall JG, Herrod $\mathrm{H}$. The Stickler syndrome presenting as a dominantly inherited cleft palate and blindness. J Med Genet 1975;12:397-400.

4 Herrmann J, France TD, Spranger JW, Opitz JM, Wiffler C. The Stickler syndrome (hereditary arthroophthalmopathy). Birth Defects Orig Artic Ser 1975;11:76-103.

5 Opitz JM, France T, Herrmann J, Spranger JW. The Stickler syndrome. NEngl J Med 1972;286:546-7.

6 Schreiner RL, McAlister WH, Marshall RE, Shearer WT. Stickler syndrome in a pedigree of Pierre Robin syndrome. Am J Dis Child 1973;126:86-90.

7 Snead MP. Hereditary vitreopathy. Eye 1996;10(P+ 6):653-63.

8 Stickler GB, Hughes W, Houchin P. Clinical features of hereditary progressive arthro-ophthalmopathy (Stickler syndrome): a survey. Genet Med 2001;3:192-6.
9 Snead MP, Yates JR. Clinical and molecular genetics of Stickler syndrome. J Med Genet 1999;36:353-9.

10 Scott JD. Congenital myopia and retinal detachment. Trans Ophthalmol Soc UK 1980;100:69-71.

11 Snead MP, Payne SJ, Barton DE, Yates JR, al Imara L, Pope FM, Scott JD. Stickler syndrome: correlation between vitreoretinal phenotypes and linkage to COL2A1. Eye 1994;8(Pt 6):609-14.

12 Francomano CA, Liberfarb RM, Hirose T, Maumenee IH, Streeten EA, Meyers DA, Pyeritz RE. The Stickler syndrome: evidence for close linkage to the structural gene for type II collagen. Genomics 1987;1:293-6.

13 Francomano CA, Liberfarb RM, Hirose T, Maumenee IH, Streeten EA, Meyers DA, Pyeritz RE. The Stickler syndrome is closely linked to COL2A1, the structural gene for type II collagen. Pathol Immunopathol Res 1988;7:104-6.

14 Ahmad NN, Ala-Kokko L, Knowlton RG, Jimenez SA, Weaver EJ, Maguire ال, Tasman W, Prockop DJ. Stop codon in the procollagen II gene (COL2A1) in a family with the Stickler syndrome (arthro-ophthalmopathy). Proc Natl Acad Sci U S A 1991;88:6624-7.

15 Ahmad NN, McDonald-McGinn DM, Zackai EH, Knowlton RG, LaRossa D Dimascio J, Prockop DJ. A second mutation in the type II procollagen gene (COL2Al) causing Stickler syndrome (arthro-ophthalmopathy) is also a premature termination codon. Am J Hum Genet 1993;52:39-45.

16 Ahmad NN, Dimascio J, Knowlton RG, Tasman WS. Stickler syndrome. A mutation in the non-helical $3^{\prime}$ end of type II procollagen gene. Arch Ophthalmol 1995;113:1454-7.

17 Brown DM, Nichols BE, Weingeist TA, Sheffield VC, Kimura AE, Stone EM Procollagen II gene mutation in Stickler syndrome. Arch Ophthalmol 1992;110:1589-93.

18 Brown DM, Vandenburgh K, Kimura AE, Weingeist TA, Sheffield VC, Stone EM. Novel frameshift mutations in the procollagen 2 gene (COL2A1) associated with Stickler syndrome (hereditary arthro-ophthalmopathy). Hum Mol Genet 1995;4:141-2.

19 Richards AJ, Martin S, Yates JR, Scott JD, Baguley DM, Pope FM, Snead MP. COL2A1 exon 2 mutations: relevance to the Stickler and Wagner syndromes. Br J Ophthalmol 2000;84:364-71.

20 Ritvaniemi P, Hyland J, Ignatius J, Kivirikko KI, Prockop DJ, Ala-Kokko L. A fourth example suggests that premature termination codons in the COL2Al gene are a common cause of the Stickler syndrome: analysis of the COL2A gene by denaturing gradient gel electrophoresis. Genomics 1993;17:218-21.

21 Williams CJ, Ganguly A, Considine E, McCarron S, Prockop DJ, WalshVockley C, Michels VV. A-2 $\rightarrow$ G transition at the $3^{\prime}$ acceptor splice site of IVS17 characterizes the COL2A1 gene mutation in the original Stickler syndrome kindred. Am J Med Genet 1996;63:461-7.

22 Richards AJ, Baguley DM, Yates JR, Lane C, Nicol M, Harper PS, Scott JD, Snead MP. Variation in the vitreous phenotype of Stickler syndrome can be caused by different amino acid substitutions in the $X$ position of the type II collagen Gly-X-Y triple helix. Am J Hum Genet 2000;67:1083-94.

23 Richards AJ, Scott JD, Snead MP. Molecular genetics of rhegmatogenous retinal detachment. Eye 2002;16:388-92.

24 Van der Hout AH, Verlind E, Scheffer H, Hooymans JMM. A new family with a mutation in exon 2 of COL2Al and Stickler syndrome without systemic manifestations (abstract). Am J Hum Genet 2001;69.

25 Donoso LA, Edwards AO, Frost AT, Ritter R, Ahmad NN, Vrabec T, Rogers J, Meyer D. Identification of a stop codon mutation in exon 2 of the collagen 2A1 gene in a large Stickler syndrome family. Am J Ophthalmol 2002;134:720-7.

26 Parma ES, Korkko J, Hagler WS, Ala-Kokko L. Radial perivascular retinal degeneration: a key to the clinical diagnosis of an ocular variant of Stickler syndrome with minimal or no systemic manifestations. Am J Ophthalmol 2002; 134:728-34

27 Snead MP, Yates JR, Williams R, Payne SJ, Pope FM, Scott JD. Stickler syndrome type 2 and linkage to the COL11Al gene. Ann N Y Acad Sci 1996;785:331-2

28 Richards AJ, Yates JR, Williams R, Payne SJ, Pope FM, Scott JD, Snead MP. A family with Stickler syndrome type 2 has a mutation in the COL11A1 gene resulting in the substitution of glycine 97 by valine in alpha 1 (XI) collagen. Hum Mol Genet 1996;5:1339-43.

29 Annunen S, Korkko J, Czarny M, Warman ML, Brunner HG, Kaariainen H, Mulliken JB, Tranebjaerg L, Brooks DG, Cox GF, Cruysberg JR, Curtis MA Davenport SL, Friedrich CA, Kaitila I, Krawczynski MR, Latos-Bielenska A, Mukai S, Olsen BR, Shinno N, Somer M, Vikkula M, Zlotogora J, Prockop DJ, Ala-Kokko L. Splicing mutations of 54-bp exons in the COL11A1 gene cause Marshall syndrome, but other mutations cause overlapping Marshall/Stickler phenotypes. Am J Hum Genet 1999;65:974-83.

30 Martin S, Richards AJ, Yates JR, Scott JD, Pope M, Snead MP. Stickler syndrome: further mutations in COL11A1 and evidence for additional locus heterogeneity. Eur J Hum Genet 1999;7:807-14.

31 Hall JG, Froster-Iskenius UG, Allanson JE. Handbook of normal physical measurements. New York: Oxford University Press, 1989.

32 Beighton P. McKusick's heritable disorders of connective tissue, 5th ed. St Louis: Mosby, 1993

33 British Society of Audiology. Recommended procedures for pure-tone audiometry using a manually operated instrument. $\mathrm{Br} J$ Audiol $1981 ; 15: 213-6$.

34 Seery CM, Pruett RC, Liberfarb RM, Cohen BZ. Distinctive cataract in the Stickler syndrome. Am J Ophthalmol 1990;110:143-8.

35 Scott JD. Duke-Elder lecture. Prevention and perspective in retinal detachment. Eye 1989;3(Pt 5):491-515.

36 Marshall D. Report of a kindred with ocular abnormalities and hearing defect. Am J Ophthalmol 1958;45:143-56.

37 Parentin F, Sangalli A, Mottes M, Perissutti P. Stickler syndrome and vitreoretinal degeneration: correlation between locus mutation and vitreous 
phenotype. Apropos of a case. Graefe's Arch Clin Exp Ophthalmol $2001 ; 239: 316-9$

38 Parentin F. Reply to McLeod, et al.; Vitreous phenotype: genotype correlation in Stickler syndrome. Graefe's Arch Clin Exp Ophthalmol 2002;240:66.

39 McLeod D, Black GC, Bishop PN. Vitreous phenotype:genotype correlation in Stickler syndrome. Graefe's Arch Clin Exp Ophthalmol 2002;240:63-5.

40 Snead MP, Snead DR, Richards AJ, Harrison JB, Poulson AV, Morris AH, Sheard RM, Scott JD. Clinical, histological and ultrastructural studies of the posterior hyaloid membrane. Eye 2002;16:447-53.

41 Liberfarb RM, Goldblatt A. Prevalence of mitral-valve prolapse in the Stickler syndrome. Am J Med Genet 1986;24:387-92.

42 Ahmad N, Richards AJ, Murfett HC, Shapiro L, Scott JD, Yates JR, Norton J Snead MP. Prevalence of mitral valve prolapse in Stickler syndrome. Am J Med Genet 2003;1 16:234-7.

43 Wagner H. Ein bisher unbekanntes Erbleiden des Auges (degeneratio hyaloideo-retinalis hereditaria), beobachtet im Kanton Zurich. Klin Mbl Augenheilk 1938;100:840-58.

44 Brown DM, Graemiger RA, Hergersberg M, Schinzel A, Messmer EP, Niemeyer G, Schneeberger SA, Streb LM, Taylor CM, Kimura AE. Genetic linkage of Wagner disease and erosive vitreoretinopathy to chromosome 5q13-14. Arch Ophthalmol 1995;113:671-5.
45 Weissenbacher G, Zweymuller E. Coincidental occurrence of Pierre Robin and foetal chondrodysplasia. Monatsschr Kinderheilkd 1964;112:315-7.

46 Pihlajamaa T, Prockop DJ, Faber J, Winterpacht A, Zabel B, Giedion A, Wiesbauer P, Spranger J, Ala-Kokko L. Heterozygous glycine substitution in the COL1 1A2 gene in the original patient with the Weissenbacher-Zweymuller syndrome demonstrates its identity with heterozygous OSMED (nonocular Stickler syndrome). Am J Med Genet 1998;80:115-20.

47 Griffith AJ, Sprunger LK, Sirko-Osadsa DA, Tiller GE, Meisler MH, Warman ML. Marshall syndrome associated with a splicing defect at the COL1 1A1 locus. Am J Hum Genet 1998:62:816-23.

48 Shanske A, Bogdanow A, Shprintzen RJ, Marion RW. Marshall syndrome and a defect at the COL11A1 locus. Am J Hum Genet 1998;63:1558-61.

49 Ayme S, Preus $M$. The Marshall and Stickler syndromes: objective rejection of lumping. J Med Genet 1984;21:34-8.

50 Shanske AL, Bogdanow A, Shprintzen RJ, Marion RW. The Marshall syndrome: report of a new family and review of the literature. Am J Med Genet 1997;70:52-7.

51 Keith CG, Dobbs RH, Shaw DG, Cottrall K. Abnormal facies, myopia, and short stature. Arch Dis Child 1972;47:787-93.

52 Ruppert ES, Buerk E, Pfordresher MF. Hereditary hearing loss with saddlenose and myopia. Arch Otolaryngol 1970;92:95-8. 